\title{
Popping expansion and yield responses of popcorn cultivars under different row spacings and plant populations
}

\author{
José Antonio de Souza Rossato Junior(1), Disnei Amélio Cazetta( ${ }^{(2)}$ \\ José Carlos Barbosa ${ }^{(2)}$ and Domingos Fornasieri Filho(2)
}

\begin{abstract}
(1)Faculdade Dr. Francisco Maeda, Rodovia Jerônimo Nunes Macedo, Km 01, CEP 14500-000 Ituverava, SP, Brazil. E-mail: jose.rossato@yahoo.com.br (2)Universidade Estadual Paulista, Campus de Jaboticabal, Via de Acesso Prof. Paulo Donato Castellane, CEP 14884-900 Jaboticabal, SP, Brazil. E-mail: disnei@fcav.unesp.br, jcbarbosa@fcav.unesp.br, fornasieri@fcav.unesp.br
\end{abstract}

\begin{abstract}
The objective of this work was to evaluate the agronomic traits and the popping expansion index of three Brazilian popcorn cultivars under different row spacings and plant populations. The trials were performed during two crop seasons, under field conditions. The experimental design used was a randomized complete block, in a split-split plot, with 27 treatments and four replicates. Treatments were represented in a triple factorial arrangement: three row spacings $(0.40,0.60$, and $0.80 \mathrm{~m})$, three plant populations $(40,000,60,000$, and 80,000 plants per hectare), and three popcorn cultivars (IAC-TC 01, IAC 12, and Zelia). The increase in plant population causes a reduction in the number of grains per ear, lower prolificacy, and grain weight loss. Cultivar grain yield is affected by row spacing and popcorn plant population. Cultivar IAC 12 shows highest grain yield under row spacings of 0.40 and $0.60 \mathrm{~m}$ and plant population between 60,000 and 80,000 plants per hectare. The popping expansion index is not affected by row spacing or plant population.
\end{abstract}

Index terms: Zea mays, plant density, popping expansion index, spatial arrangement.

\section{Capacidade de expansão e produtividade de cultivares de milho-pipoca sob diferentes espaçamentos entre as linhas e população de plantas}

\begin{abstract}
Resumo - O objetivo deste trabalho foi avaliar os caracteres agronômicos e o índice de capacidade de expansão de três cultivares de milho-pipoca brasileiras sob diferentes espaçamentos entre linhas e populações de plantas. Os ensaios foram realizados durante dois anos agrícolas, em condições de campo. Utilizou-se o delineamento experimental de blocos ao acaso, com parcelas subsubdivididas, 27 tratamentos e quatro repetições. Os tratamentos foram representados em arranjo fatorial triplo: três espaçamentos entre as linhas $(0,40,0,60$ e $0,80 \mathrm{~m})$, três populações de plantas $(40.000,60.000$ e 80.000 plantas por hectare) e três cultivares de milho-pipoca (IAC-TC 01, IAC 12 e Zelia). O aumento da população de plantas ocasiona redução no número de grãos por espiga, menor prolificidade e perda de massa de grãos. O rendimento de grãos das cultivares é afetado pelos espaçamentos entre as linhas e a população de plantas de milho-pipoca. A cultivar IAC 12 apresenta maior produtividade de grãos sob os espaçamentos de 0,40 e $0,60 \mathrm{~m}$ e a população de plantas entre 60.000 e 80.000 plantas por hectare. O índice de capacidade de expansão não é afetado pelo espaçamento ou pela população de plantas.
\end{abstract}

Termos para indexação: Zea mays, densidade de plantas, índice de capacidade de expansão, arranjo espacial.

\section{Introduction}

Popcorn yield and total production has greatly increased in Brazil (Mora \& Scapim, 2007). However, this amount is still not enough to meet the domestic market needs, and a policy is to import popcorn mainly from Argentina and the USA (Scapim et al., 2006). Therefore, new agricultural features, process adjustments among farmers, and specific agronomic research for popcorn cultivars will be instrumental for Brazil to acquire self-sufficiency in the national popcorn business.

The popping expansion index (PEI), represented by the volume of popcorn from the mass of kernels, is the main model to evaluate popcorn quality worldwide (Pereira Filho et al., 2010). However, this parameter was only officially implemented in the Brazilian national market recently (Sislegis, 2011). 
Popcorn yield is also affected by plant spatial arrangement (Fornasieri Filho, 2007), which can be manipulated through changes in row spacing and plant density (Silva et al., 2006; Cruz et al., 2007). However, to achieve an ideal plant population, it is necessary to consider some technical features, such as: cultivar, plant spacing distribution, soil fertility and moisture content, planting season, expected yield, and the technology level adopted by farmers (Flesch \& Vieira, 2004; Sangoi et al., 2009).

Reduced row spacing can promote greater soil cover, which is useful for weed management (Balbinot Junior \& Fleck, 2005). Furthermore, equidistant plant spacing can improve the use of environmental resources (Demétrio et al., 2008; Brachtvogel et al., 2009) through the reduction of intraspecific plant competition, increasing soil nutrient availability, water uptake, light, and $\mathrm{CO}_{2}$ assimilation in the plant community (Sangoi et al., 2002).

Low plant density promotes smaller plant-size, lower ear height, higher prolificacy, as well as grain weight and grains per ear, in comparison to plant populations over 90,000 plants per hectare (Cruz et al., 2007; Revoredo et al., 2009). In addition, plant population and row spacing combinations can result in different agronomic traits and yield (Cruz et al., 2007; Demétrio et al., 2008). However, there is no indication that the PEI in popcorn may be altered by plant spatial arrangement, even though this index is an essential parameter for the trading market (Brugnera et al., 2003).

While estimating the quality of Brazilian popcorn, Pacheco et al. (1996) found a PEI average of $15.4 \mathrm{~mL} \mathrm{~mL}^{-1}$ among 29 popcorn marketed samples tested. Currently, a minimum average of $30.0 \mathrm{~mL} \mathrm{~mL}^{-1}$ is required by the Brazilian Government.

The objective of this work was to evaluate the agronomic traits and the popping expansion index PEI of three Brazilian popcorn cultivars under different row spacings and plant populations.

\section{Materials and Methods}

The experiments were carried out in field at Faculdade de Ciências Agrárias e Veterinárias of Universidade Estadual Paulista, Campus de Jaboticabal, state of São Paulo, Brazil $\left(21^{\circ} 14^{\prime} 05^{\prime \prime S}\right.$, $48^{\circ} 17^{\prime} 09^{\prime \prime} \mathrm{W}$, at $613 \mathrm{~m}$ above sea level). The soil of the area is classified as Latossolo Vermelho eutrófico típico (Rhodic Eutrudox), and the topography is gently undulating. The climate of the region, according to Köeppen classification, is Aw, a tropical climate with dry winters and hot and humid summers (Centro de Pesquisas Meteorológicas e Climáticas Aplicadas à Agricultura, 2014).

Before the experiments, soil samples were collected (0.0-0.20 $\mathrm{m}$ deep) from the experimental field and chemically analyzed. The results showed: $5.9 \mathrm{pH}$ in $\mathrm{CaCl}_{2} ; 26.0 \mathrm{~g} \mathrm{dm}^{-3} \mathrm{SOM}$; $68.0 \mathrm{mg} \mathrm{dm}^{-3}$ P-resin; $3.6 \mathrm{mmol}_{\mathrm{c}} \mathrm{dm}^{-3} \mathrm{~K} ; 51.0 \mathrm{mmol}_{\mathrm{c}} \mathrm{dm}^{-3} \mathrm{Ca} ; 14.0 \mathrm{mmol}_{\mathrm{c}}$ $\mathrm{dm}^{-3} \mathrm{Mg} ; 20.0 \mathrm{mmol}_{\mathrm{c}} \mathrm{dm}^{-3} \mathrm{H}+\mathrm{Al} ; 88.6 \mathrm{mmol}_{\mathrm{c}} \mathrm{dm}^{-3}$ cation exchange capacity; $77 \%$ base saturation; and $0.3,4.1,24.0,17.5,3.2$, and $5.0 \mathrm{mg} \mathrm{dm}^{-3} \mathrm{~B}, \mathrm{Cu}, \mathrm{Fe}$, $\mathrm{Mn}, \mathrm{Zn}$, and $\mathrm{S}-\mathrm{SO}_{4}$, respectively.

In the spring, the soil was scarified, plowed, and disked twice by tillage equipment, and 30,60, and $60 \mathrm{~kg} \mathrm{ha}^{-1} \mathrm{~N}, \mathrm{P}_{2} \mathrm{O}_{5}$, and $\mathrm{K}_{2} \mathrm{O}$, respectively were added as fertilizer, according to Cantarella et al. (1996).

The experimental design was a randomized complete block, with four replicates. Treatments consisted of a triple factorial arrangement $(3 \times 3 \times 3)$ : three popcorn cultivars (Zelia, a triple hybrid; IAC 12, a simple hybrid; and IAC TC-01, a top-cross hybrid), three row spacings $(0.40,0.60$, and $0.80 \mathrm{~m})$, and three plant populations $(40,000,60,000$, and 80,000 plants per hectare). Each plot was comprised of eight plant rows (4 $\mathrm{m}$ each one), with six intermediate rows harvested manually for evaluation.

Plantings were carried out on $10 / 21 / 2002$ for the $2002 / 2003$ crop season and on $10 / 13 / 2003$ for the $2003 / 2004$ crop season. The seeds were distributed manually, 30\% above the desired plant population. Fifteen days after planting (DAP), a manual thinning was done to establish the number of plants in each plot according to the respective plant population treatment.

A split application of ammonium nitrate $\left(180 \mathrm{~kg} \mathrm{ha}^{-1}\right)$ was added at the four- and five-leaf growth stage, following Cantarella et al. (1996). An integrated pest management procedure was done to control leaf-feeding injury from fall armyworm (Spodoptera frugiperda). Registered pesticides were sprayed twice (8 and 18 DAP) during the first crop season and three times $(12,20$, and 30 DAP) during the second crop season. For weed management, registered herbicides were sprayed both seasons.

The following traits were evaluated: prolificacy, determined by the number of ears divided by the

Pesq. agropec. bras., Brasília, v.48, n.12, p.1538-1545, dez. 2013 DOI: $10.1590 / \mathrm{S} 0100-204 X 2013001200002$ 
number of plants; number of kernels per ear, calculated by the number of kernels divided by the number of ears; weight of 100 grains (13\% humidity basis); grain yield $\left(\mathrm{kg} \mathrm{ha}^{-1}\right)$; and popping expansion index $\left(\mathrm{mL} \mathrm{g}^{-1}\right)$, determined by the popcorn volume divided by $100 \mathrm{~g}$ of kernels, in a hot air popcorn popper, according to Matta \& Viana (2001).

All data collected were submitted to analysis of variance in a randomized complete block, in a $3 \times 3 \times 3$ factorial arrangement - three popcorn cultivars, three row spacings, and three plant populations using the program SAS Proc GLM, version 9.1 (SAS Institute, Cary, NC, USA). Means were compared using the Tukey test, at 5\% probability, and interactions sliced were significantly different. The response surface methodology (RSM) was applied to analyze the effect of plant population and row spacing (factors) on cultivar grain yield (responses), according to Myers et al. (2009).

\section{Results and Discussion}

A significant reduction in prolificacy was observed as the plant population increased. Natural resources, such as water and nutrients, are limited, which causes intraspecific plant competition, decreasing dry plant mass (Gross et al., 2006) and number of ears produced per plant (Revoredo et al., 2009).

Prolificacy is a plant characteristic that may vary among corn cultivars, even under the same plant density, leading to different results (Cruz et al., 2007; Goes et al., 2013).

The highest prolificacy was observed in cultivar IAC 12 for both crop seasons (Table 1). IAC 12 also showed a consistent prolificacy in the interaction sliced across plant population and cultivars in the first crop season (Table 2). However, the highest density (80,000 plants per hectare) promoted no difference among the popcorn cultivars for number of ears per plant. Similar results were reported by Leonello et al. (2009), who assessed the same popcorn cultivars.

No interactions were found in high plant populations and row spacings for kernels per ear. However, under different plant populations, results were significantly different during the second season, in which the highest plant population $(80,000$ plants per hectare) resulted in a reduced number of kernels per ear. According to Strieder et al. (2008), oscillations on the leaf area index and photosynthesis rates, caused by plant spatial arrangement, may be observed. Consequently, the following occur: phenomenon of female sterility and induction of pollination failure, which can result in malformed corn kernels (Sangoi et al., 2005) and in a decrease in the number of kernels per ear (Marchão et al., 2006).

Considering the cultivars evaluated, the Zelia popcorn hybrid presented superior values for kernels per ear. However, grain weight was not as high as the number of kernels. The highest grain weight was reported for the IAC TC-01 popcorn hybrid, on both crop seasons. Slicing interaction was observed across popcorn cultivars and row population, in the first crop season (Table 3). IAC TC-01 under a row spacing of $0.60 \mathrm{~m}$ presented lower grain weight than at 0.40 and $0.80 \mathrm{~m}$. In contrast, IAC 12 and Zelia were not affected by row spacing. To date, no impact of row spacing on grain weight has been reported (Flesh \& Vieira, 2004; Amaral Filho et al., 2005; Demétrio et al., 2008).

The results obtained for agronomic traits had a direct impact on grain yield during the first and second crop seasons. Increasing corn plant population promotes a greater number of ears per area and grain yield increment (Fornasieri Filho, 2007). However, plant compensation occurs as far as the optimum plant density, and the number of ears is not sufficient to compensate losses of grain weight and number. Higher grain yield was not reached under the highest plant density. Other authors reported yield reduction under higher plant populations (Silva et al., 2006; Demétrio et al., 2008; Sangoi et al., 2009). Probably, the required natural resources were not sufficient for all plants, and intraspecific plant competition compromised grain yield (Brachtvogel et al., 2009; Revoredo et al., 2009). In this case, seed costs increased without any extra grain yield benefits.

Increases in grain yield under high plant populations could be achieved in a high fertility soil, with more nutrient availability, as suggested by Hörbe et al. (2013), or with the increase of nitrogen fertilization (Goes et al., 2013). Additionally, expected grain yield could be an effective tool for adjusting corn seeding rates and fertilization. Although increasing plant population is a strategy to increase yield, environmental factors, such as moisture and nutrients available, should also be considered.

Spatial arrangement is the most important tactic to enhance corn yield (Silva et al., 2006; Cruz et al., 
2007), and can be manipulated by adjustments in row spacing and plant density. In order to promote yield gain, other popcorn cultivar traits should be analyzed, such as life cycle, plant architecture, adaptability, and stability (Carpentieri-Pípolo et al., 2005; Strieder et al., 2008).

IAC 12 presented the highest yield among the popcorn cultivars tested for both crop seasons. However, the cultivar Zelia showed yield as low as the one reported by Leonello et al. (2009). According to these authors, Zelia is highly susceptible to maize bushy stunt phytoplasma (MBSP), which is a disease that may decrease yield potential expression. MBSP symptoms were not measured, but were observed for this cultivar during both crop seasons. MBSP is transmitted by the spittlebug Dalbulus maidis (Hemiptera: Cicadellidae). However, there is no indication of MBSP occurrences related to row spacing or plant density, only to the vector-insect population present, cultivar susceptibility, and plant phenological stage during the insect attack (Kappes et al., 2013).
An interaction slice of cultivar and plant population density in the second crop season (2003/2004) showed similar results among all popcorn cultivars tested under 60,000 plants per hectare. However, IAC 12 was the best cultivar under higher $(80,000$ plants per hectare) and lower $(40,000$ plants per hectare) plant density (Table 4).

Considering plant population and row spacing as agronomic strategies for spatial arrangement adjustments, it was possible to assess the combination of both parameters for each popcorn cultivar by surface responses. The analysis showed different yield performance under this combination system for the popcorn cultivars tested. IAC TC-01 presented a tendency for higher grain yield under plant population around 65,000 plants per hectare, with smaller row spacing in the first crop season (Figure $1 \mathrm{~A}$ ). The increase in row spacing promoted grain yield reduction regardless of the plant population. During the second crop season, the ideal row spacing for this hybrid was around $0.60 \mathrm{~m}$ for a $2,900 \mathrm{~kg} \mathrm{ha}^{-1}$ grain yield

Table 1. Mean number of ears per plant (NEP), number of kernels per ear (NKE), weight of 100 grains (WHG), grain yield (GY), and the combined analyses of variance across three popcorn cultivars, under different row spacings (RS) and plant populations (PP), during two crop seasons ${ }^{(1)}$.

\begin{tabular}{|c|c|c|c|c|c|c|c|c|}
\hline \multirow[t]{2}{*}{ Treatment } & \multicolumn{2}{|c|}{ NEP } & \multicolumn{2}{|c|}{ NKE } & \multicolumn{2}{|c|}{ WHG (g) } & \multicolumn{2}{|c|}{ GY $\left(\mathrm{kg} \mathrm{ha}^{-1}\right)$} \\
\hline & $2002 / 2003$ & $2003 / 2004$ & $2002 / 2003$ & $2003 / 2004$ & $2002 / 2003$ & $2003 / 2004$ & $2002 / 2003$ & $2003 / 2004$ \\
\hline \multicolumn{9}{|l|}{ Row spacing (m) } \\
\hline 0.40 & 1.13 & $1.43 \mathrm{a}$ & 529 & 513 & 13.06 & 9.64 & $2,587 \mathrm{a}$ & 2,889 \\
\hline 0.60 & 1.15 & $1.32 \mathrm{~b}$ & 555 & 520 & 12.50 & 9.92 & $2,514 \mathrm{a}$ & 2,744 \\
\hline 0.80 & 1.06 & $1.41 \mathrm{ab}$ & 526 & 529 & 12.59 & 10.05 & $2,364 b$ & 2,781 \\
\hline F test (RS) & $1.70^{\mathrm{ns}}$ & $3.95 *$ & $1.40^{\mathrm{ns}}$ & $1.84^{\mathrm{ns}}$ & $1.65^{\mathrm{ns}}$ & $2.26^{\mathrm{ns}}$ & $7.62 * *$ & $2.95^{\mathrm{ns}}$ \\
\hline \multicolumn{9}{|l|}{ Plant population (plants per hectare) } \\
\hline 40,000 & $1.39 \mathrm{a}$ & $1.65 \mathrm{a}$ & 522 & $536 \mathrm{a}$ & 13.13 & $10.02 \mathrm{a}$ & $2,161 \mathrm{c}$ & $2,558 \mathrm{~b}$ \\
\hline 60,000 & $1.12 b$ & $1.40 \mathrm{~b}$ & 545 & $517 \mathrm{ab}$ & 12.65 & $10.04 \mathrm{a}$ & $2,754 a$ & $2,963 \mathrm{a}$ \\
\hline 80,000 & $0.83 \mathrm{c}$ & $1.11 \mathrm{c}$ & 543 & $508 b$ & 12.37 & $9.55 b$ & $2,552 \mathrm{~b}$ & $2,893 \mathrm{a}$ \\
\hline F test (PP) & $75.54 * *$ & $73.33 * *$ & $0.89^{\text {ns }}$ & $5.10 * *$ & $2.74^{\mathrm{ns}}$ & $3.90^{*}$ & $53.76 * *$ & $24.48 * *$ \\
\hline \multicolumn{9}{|l|}{ Popcorn cultivar (PC) } \\
\hline IAC TC-01 & $1.15 \mathrm{a}$ & $1.36 \mathrm{~b}$ & $504 b$ & $491 b$ & $13.63 \mathrm{a}$ & $10.31 \mathrm{a}$ & $2,271 b$ & $2,720 b$ \\
\hline IAC 12 & $1.25 \mathrm{a}$ & $1.50 \mathrm{a}$ & $547 \mathrm{ab}$ & $511 b$ & $11.94 b$ & $9.50 \mathrm{~b}$ & $3,039 \mathrm{a}$ & $3,045 \mathrm{a}$ \\
\hline Zelia & $0.94 b$ & $1.30 \mathrm{~b}$ & $559 \mathrm{a}$ & $560 \mathrm{a}$ & $12.58 b$ & $9.80 \mathrm{~b}$ & $2,157 \mathrm{~b}$ & $2,649 \mathrm{~b}$ \\
\hline F test $(\mathrm{PC})$ & $24.18 * *$ & $10.52 * *$ & $4.75^{*}$ & $31.26^{* *}$ & $13.44 * *$ & $8.56 * *$ & $136.44 * *$ & $23.31 * *$ \\
\hline F test (RS x PP) & $0.08^{\mathrm{ns}}$ & $1.57^{\mathrm{ns}}$ & $1.94^{\mathrm{ns}}$ & $0.19^{\text {ns }}$ & $0.34^{\mathrm{ns}}$ & $0.42^{\text {ns }}$ & $3.36^{*}$ & $1.60^{\mathrm{ns}}$ \\
\hline F test (RS x PC) & $1.13^{\mathrm{ns}}$ & $0.81^{\mathrm{ns}}$ & $0.55^{\mathrm{ns}}$ & $0.98^{\mathrm{ns}}$ & $2.83 *$ & $0.10^{\mathrm{ns}}$ & $3.87 * *$ & $0.90^{\mathrm{ns}}$ \\
\hline$F$ test $(\mathrm{PP} \times \mathrm{PC})$ & $2.62 * *$ & $0.40^{\mathrm{ns}}$ & $0.35^{\mathrm{ns}}$ & $1.51^{\mathrm{ns}}$ & $0.69^{\mathrm{ns}}$ & $1.22^{\mathrm{ns}}$ & $3.37 *$ & $3.04 *$ \\
\hline $\mathrm{F}$ test $(\mathrm{RS} \times \mathrm{PP} \times \mathrm{PC})$ & $0.32^{\mathrm{ns}}$ & $0.54^{\mathrm{ns}}$ & $1.67^{\mathrm{ns}}$ & $0.77^{\mathrm{ns}}$ & $0.36^{\mathrm{ns}}$ & $0.49^{\text {ns }}$ & $2.48^{*}$ & $1.32^{\mathrm{ns}}$ \\
\hline DMS (Tukey test, at 5\% probability) & 0.11 & 0.10 & 89.96 & 21.18 & 0.79 & 0.48 & 138.93 & 148.10 \\
\hline Blocks & $11.85 * *$ & $3.01 *$ & $0.19^{\text {ns }}$ & $1.50^{\mathrm{ns}}$ & $2.78^{*}$ & $1.37^{\mathrm{ns}}$ & $1.74^{\mathrm{ns}}$ & $1.88^{\mathrm{ns}}$ \\
\hline CV $(\%)$ & 17.53 & 13.52 & 14.85 & 7.21 & 10.99 & 8.53 & 9.90 & 9.37 \\
\hline
\end{tabular}

${ }^{(1)}$ Only means within same factor and column should be compared. If letter following mean is similar, there is no significant difference at

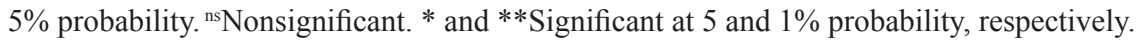


(Figure $1 \mathrm{~B}$ ). To modify row spacing for this popcorn hybrid, changes in population density are required.

Cultivar IAC 12 presented similar results and reached superior grain yield with the planting combination of 65,000 plants per hectare and a row spacing of $0.40 \mathrm{~m}$ during the first crop season (Figure 1 C). In the next crop season, this hybrid presented the highest yield at the range of 0.40 to $0.50 \mathrm{~m}$ and 77,000 to 80,000 plants per hectare, for row spacing and plant density, respectively (Figure $1 \mathrm{D})$.

The cultivar Zelia was little affected by plant population and showed a greater flexibility in maintaining grain yield with different row spacings (Figure $1 \mathrm{E}$ ). The system combination of row spacing around $0.40 \mathrm{~m}$ and 75,000 to 80,000 plants per hectare or 0.70 to $0.80 \mathrm{~m}$ and 65,000 to 80,000 plants per hectare caused an increase in grain yield. In this case, narrower row spacing would provide greater soil cover for more efficient weed management (Balbinot Junior \& Fleck, 2005). In the second season (2003/2004), row spacing lower than $0.5 \mathrm{~m}$ under different plant population densities was the best combination (Figure $1 \mathrm{~F}$ ).

Table 2. Interaction of number of ears per plant sliced across plant population and popcorn cultivars, during the 2002/2003 crop season ${ }^{(1)}$.

\begin{tabular}{lcccc}
\hline $\begin{array}{l}\text { Population } \\
\text { (plants per hectare) }\end{array}$ & \multicolumn{3}{c}{ Cultivar } & F test \\
\cline { 2 - 4 } 40,000 & $1.41 \mathrm{Ba}$ & $1.64 \mathrm{Aa}$ & $1.12 \mathrm{Ca}$ & $20.64^{* *}$ \\
60,000 & $1.18 \mathrm{Ab}$ & $1.23 \mathrm{Ab}$ & $0.95 \mathrm{Ba}$ & $6.67^{* *}$ \\
80,000 & $0.85 \mathrm{Ac}$ & $0.90 \mathrm{Ac}$ & $0.74 \mathrm{Ab}$ & $2.11^{\mathrm{ns}}$ \\
\hline F test & $25.30^{* *}$ & $42.74 * *$ & $11.73^{* *}$ & \\
DMS (Tukey test, at 5\% probability) $=0.19$ & & \\
\hline
\end{tabular}

${ }^{(1)}$ Means followed by different letters, uppercase in the rows and lowercase in the columns, differ by the $\mathrm{F}$ test, at $5 \%$ probability. ${ }^{\mathrm{n}}$ Nonsignificant. **Significant at $1 \%$ probability.

Table 3. Interaction of weight of 100 grains (g) sliced across row spacing and popcorn cultivars, during the 2002/2003 crop season $^{(1)}$.

\begin{tabular}{lcccc}
\hline $\begin{array}{l}\text { Row spacing } \\
(\mathrm{m})\end{array}$ & \multicolumn{3}{c}{ Cultivar } & F test \\
\cline { 2 - 4 } & IAC TC-01 & IAC 12 & Zelia & \\
\hline 0.40 & $14.17 \mathrm{Aa}$ & $12.03 \mathrm{Ba}$ & $12.97 \mathrm{ABa}$ & $7.07^{* *}$ \\
0.60 & $12.57 \mathrm{Ab}$ & $12.30 \mathrm{Aa}$ & $12.64 \mathrm{Aa}$ & $0.20^{\text {ns }}$ \\
0.80 & $14.15 \mathrm{Aa}$ & $11.49 \mathrm{Ba}$ & $12.12 \mathrm{Ba}$ & $11.83^{* *}$ \\
\hline F test & $5.15^{* *}$ & $1.04^{\mathrm{ns}}$ & $1.12^{\mathrm{ns}}$ & \\
\multicolumn{2}{l}{ DMS (Tukey test, at 5\% probability) $=1.36$} & & \\
\hline
\end{tabular}

${ }^{(1)}$ Means followed by different letters, uppercase in the rows and lowercase in the columns, differ by the $\mathrm{F}$ test, at $5 \%$ probability. ${ }^{\mathrm{ns}}$ Nonsignificant. ** Significant at $1 \%$ probability.
Usually, narrower row spacing requires seeder and harvester machine adjustments, as well as an increase in tractor power. Therefore, it is essential to determine the real benefits of row spacing reduction versus agricultural mechanization investments needed (Cruz et al., 2007; Dias et al., 2007).

Besides grain yield, another important parameter to be considered is popcorn quality, which requires a minimal PEI of $30 \mathrm{~mL} \mathrm{~g}^{-1}$, otherwise classified as "off-type" in the Brazilian domestic market (Brasil, 2011). All popping expansion results found were above $31 \mathrm{~mL} \mathrm{~g}^{-1}$ (Table 5). These PEI values were higher than the results reported by Pacheco et al. (1996), who obtained an average value of $15.38 \mathrm{~mL} \mathrm{~g}^{-1}$. Additionally, the PEI values were also higher than those reported by Nunes et al. (2002), who observed an average of $17.5 \mathrm{~mL} \mathrm{~g}^{-1}$.

Popcorn cultivars should present a high PEI, as well as a high potential grain yield. According to Brugnera et al. (2003), both characteristics are difficult to find in the same popcorn cultivar. However, IAC 12 showed the highest grain yield and a great PEI, and, therefore, should be considered. Cultivar Zelia achieved low grain yield, but promoted high PEI as also observed by Brugnera et al. (2003) and Carpentieri-Pípolo et al. (2005). A positive correlation for grain yield and PEI was suggested by Pacheco et al. (1996), but was not confirmed in the present study.

It is important to verify if any agronomic management on the fields can interfere in popcorn quality through the PEI parameter (Brugnera et al., 2003). In a previous study, Leonello et al. (2009) reported no interference in the PEI by high plant population. The three popcorn cultivars evaluated were not affected by any combination of plant spatial arrangement.

Table 4. Interaction of grain yield $\left(\mathrm{kg} \mathrm{ha}^{-1}\right)$ sliced across plant population and popcorn cultivars, during the 2003/2004 crop season ${ }^{(1)}$.

\begin{tabular}{|c|c|c|c|c|}
\hline \multirow{2}{*}{$\begin{array}{l}\text { Plant population } \\
\text { (plants per hectare) }\end{array}$} & \multicolumn{3}{|c|}{ Cultivars } & \multirow[t]{2}{*}{$\mathrm{F}$ test } \\
\hline & IAC TC-01 & IAC 12 & Zelia & \\
\hline 40,000 & $2,417 \mathrm{Bc}$ & $2,826 \mathrm{Ab}$ & $2,428 \mathrm{Bb}$ & $9.45 * *$ \\
\hline 60,000 & $3,000 \mathrm{Aa}$ & $3,046 \mathrm{Aab}$ & $2,841 \mathrm{Aa}$ & $2.00^{\text {ns }}$ \\
\hline 80,000 & $2,740 \mathrm{Bb}$ & $3,261 \mathrm{Aa}$ & $2,677 \mathrm{Bab}$ & $17.84 * *$ \\
\hline F test & $14.83 * *$ & $8.20 * *$ & $7.53 * *$ & \\
\hline \multicolumn{5}{|c|}{ DMS (Tukey test, at $5 \%$ probability $)=256.52$} \\
\hline
\end{tabular}

${ }^{(1)}$ Means followed by different letters, uppercase in the rows and lowercase in the columns, differ by the $\mathrm{F}$ test, at $5 \%$ probability. ${ }^{\text {ns }}$ Nonsignificant. **Significant at $1 \%$ probability. 

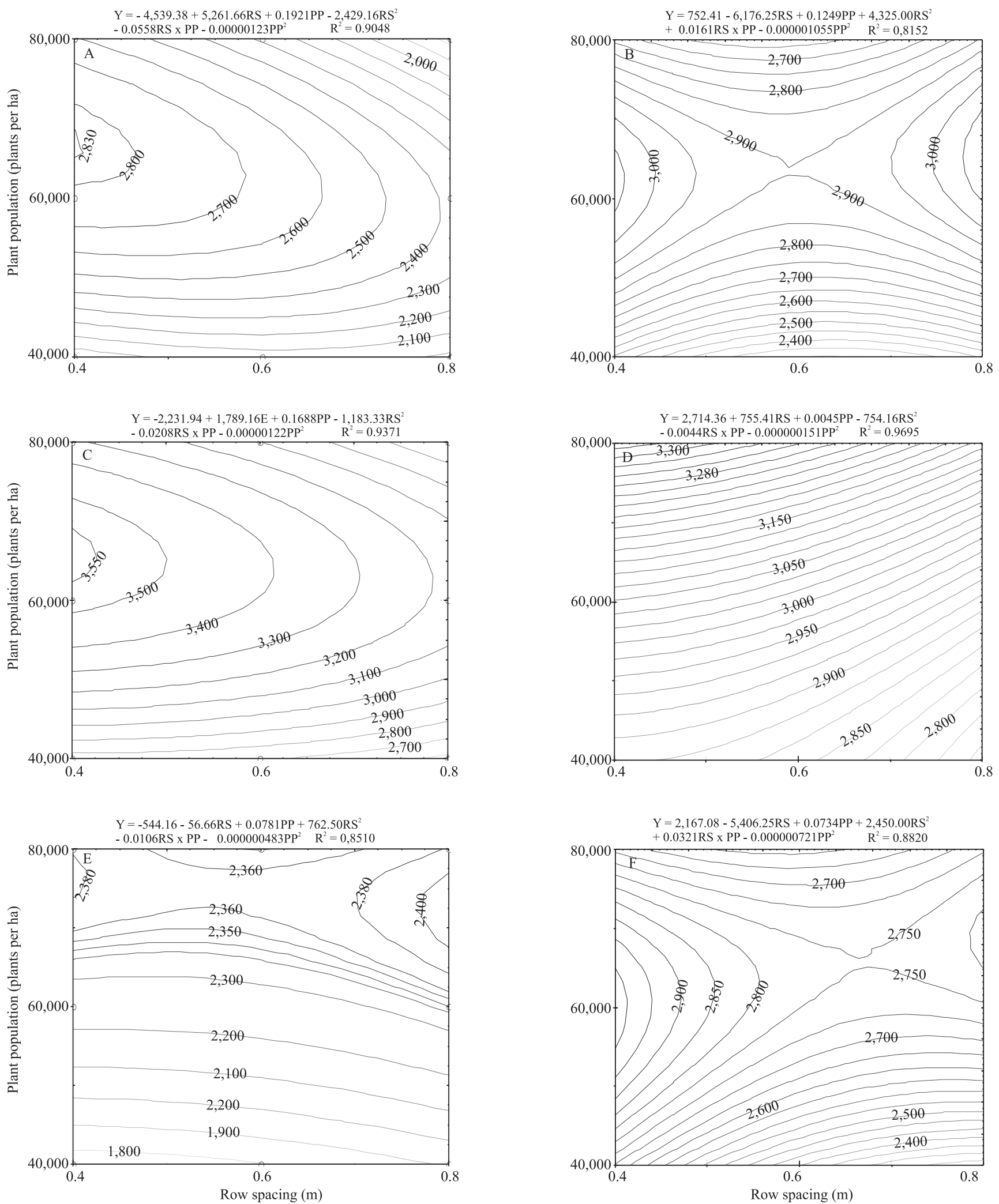

Figure 1. Surface responses of the cultivars IAC-TC 01 (A and B), IAC 12 (C and D), and Zelia (E and F), during the 2002/2003 (A, C and E) and 2003/2004 (B, D and F) crop seasons, for popcorn grain yield under different row spacings (PP) and plant populations (PP). 
Table 5. Mean popping expansion index (PEI) and the combined analyses of variance across three popcorn cultivars, under different row spacings (RS) and plant populations (PP), during two crop seasons ${ }^{(1)}$.

\begin{tabular}{llc}
\hline Treatment & \multicolumn{2}{c}{ PEI $\left(\mathrm{mL} \mathrm{g}^{-1}\right)$} \\
\cline { 2 - 3 } & $2002 / 2003$ & $2003 / 2004$ \\
\hline Row spacing $(\mathrm{m})$ & 32.25 & 32.90 \\
0.40 & 31.33 & 32.68 \\
0.60 & 31.80 & 32.88 \\
0.80 & $1.08^{\text {ns }}$ & $0.19^{\text {ns }}$ \\
\hline F test & & \\
\hline Plant population (plants per hectare) & 31.22 & 32.47 \\
40,000 & 31.68 & 32.62 \\
60,000 & 32.48 & 33.37 \\
80,000 & $2.09^{\text {ns }}$ & $2.93^{\text {ns }}$ \\
\hline F test & & \\
\hline Popcorn cultivars (PC) & 31.72 & $33,29 \mathrm{~b}$ \\
IAC TC-01 & 32.41 & $34,75 \mathrm{a}$ \\
IAC 12 & 31.25 & $30,43 \mathrm{c}$ \\
Zelia & $1.72^{\text {ns }}$ & $60,78^{* *}$ \\
\hline F test & $1.65^{\text {ns }}$ & $0.11^{\text {ns }}$ \\
\hline F test (RS x PP) & $0.69^{\text {ns }}$ & $0.20^{\text {ns }}$ \\
F test (RS x C) & $1.60^{\text {ns }}$ & $1.37^{\text {ns }}$ \\
F test (PP x C) & $0.86^{\text {ns }}$ & $0.28^{\text {ns }}$ \\
F test (RS x PP x C) & 1.49 & 0.95 \\
\hline DMS (Tukey test, at 5\% probability) & $0.88^{\text {ns }}$ & $3.62^{*}$ \\
Blocks & 8.35 & 5.15 \\
CV (\%) & & \\
\hline
\end{tabular}

${ }^{(1)}$ Only means within same factor and column should be compared. If letter following mean is similar, there is no significant difference at $5 \%$ probability. ${ }^{\text {ns }}$ Nonsignificant. $*$ and $* *$ Significant at 5 and $1 \%$ probability, respectively.

\section{Conclusions}

1. The increase in popcorn plant population causes a reduction in the number of grains per ear, lower prolificacy, and grain weight loss.

2. Cultivar grain yield is affected by row spacing and popcorn plant population.

3. Cultivar IAC 12 shows highest grain yield under row spacings of 0.40 and $0.60 \mathrm{~m}$ and plant population between 60,000 and 80,000 plants per hectare.

4. The popping expansion index is not affected by row spacing and plant population.

\section{Acknowledgments}

To Dr. Eduardo Sawazaki of Instituto Agronômico de Campinas and to Pioneer Seeds, for the popcorn seeds supplied; and to Amanda Fujikawa, for revision of the English.

\section{References}

AMARAL FILHO, J.P.R. do; FORNASIERI FILHO, D.; FARINELLI, R.; BARBOSA, J.C. Espaçamento, densidade populacional e adubação nitrogenada na cultura do milho. Revista Brasileira de Ciência do Solo, v.29, p.467-473, 2005. DOI: 10.1590/S0100-06832005000300017.

BALBINOT JUNIOR, A.A.; FLECK, N.G. Competitividade de dois genótipos de milho (Zea mays) com plantas daninhas sob diferentes espaçamentos entre fileiras. Planta Daninha, v.23, p.415-421, 2005. DOI: 10.1590/S0100-83582005000300004.

BRACHTVOGEL, E.L.; PEREIRA, F.R. da S.; CRUZ, S.C.S.; BICUDO, S.J. Densidades populacionais de milho em arranjos espaciais convencional e equidistante entre plantas. Ciência Rural, v.39, p.2334-2339, 2009. DOI: 10.1590/ S0103-84782009005000193.

BRUGNERA, A.; PINHO, R.G. von; PACHECO, C.A.P.; DURAN ALVAREZ, C.G. Resposta de cultivares de milho pipoca a doses de adubação de semeadura. Revista Ceres, v.50, p.417-429, 2003.

CANTARELLA, H.; RAIJ, B.V.; SAWAZAKI, E. Recomendações de adubação e calagem de milho pipoca. In: RAIJ, B. van; CANTARELlA, H.; QUAGGIO, J.A.; FURLANI, A.M.C. (Ed.). Recomendações de adubação e calagem para o Estado de São Paulo. 2.ed. Campinas: Instituto Agronômico, 1996. p.62-63.

CARPENTIERI-PÍPOLO, V.; RINALDI, D.A.; LIMA, V.E.N. de. Adaptabilidade e estabilidade de populações de milho-pipoca. Pesquisa Agropecuária Brasileira, v.40, p.87-90, 2005. DOI: 10.1590/S0100-204X2005000100012.

CENTRO DE PESQUISAS METEOROLÓGICAS E CLIMÁTICAS APLICADAS À AGRICULTURA. Clima dos municípios paulistas. 2013. Disponível em: <http://www.cpa. unicamp.br/outras-informacoes/clima_muni_279.html>. Acesso em: 15 dez. 2013.

CRUZ, J.C.; PEREIRA, F.T.F.; PEREIRA FILHO, I.A.; OLIVEIRA, A.C. de; MAGALHÃES, P.C. Resposta de cultivares de milho à variação em espaçamento e densidade. Revista Brasileira de Milho e Sorgo, v.6, p.60-73, 2007.

DEMÉTRIO, C.S.; FORNASIERI FILHO, D.; CAZETTA, J.O.; CAZETTA, D.A. Desempenho de híbridos de milho submetidos a diferentes espaçamentos e densidades populacionais. Pesquisa Agropecuária Brasileira, v.43, p.1691-1697, 2008. DOI: 10.1590/ S0100-204X2008001200008.

DIAS, V. de O.; SOUZA, R.S. de; ALONÇO, A. dos S. Viabilidade econômica do investimento em plataformas de colhedoras de milho em espaçamento reduzido. Engenharia Agrícola, v.27, p.463-470, 2007. DOI: 10.1590/S0100-69162007000300015.

FLESH, R.D.; VIEIRA, L.C. Espaçamentos e densidades de milho com diferentes ciclos no oeste de Santa Catarina, Brasil. Ciência Rural, v.34, p.25-31, 2004. DOI: 10.1590/ S0103-84782004000100005.

FORNASIERI FILHO, D. Manual da cultura do milho. Jaboticabal: Funep, 2007. 574p.

GOES, R.J.; RODRIGUES, R.A.F.; TAKASU, A.T.; ARF, O.; ANDRADE, J.A. de C. Fertilizantes nitrogenados e densidades de 
semeadura para a cultura do milho irrigado no inverno. Revista Brasileira de Milho e Sorgo, v.12, p.128-137, 2013.

GROSS, M.R.; PINHO, R.G.; BRITO, A.H. de. Adubação nitrogenada, densidade de semeadura e espaçamento entre fileiras na cultura do milho em sistema de plantio direto. Ciência e Agrotecnologia, v.30, p.387-393, 2006. DOI: 10.1590/ S1413-70542006000300001.

HÖRBE, T.A.N.; AMADO, T.J.C.; FERREIRA, A.O.; ALBA, P.J. Optimization of corn plant population according to management zones in Southern Brazil. Precision Agriculture, v.14, 450-465, 2013. DOI: 10.1007/s11119-013-9308-7.

KAPPES, C.; ANDRADE, J.A. da C.; ARF, O. Efeito dos arranjos espaciais de plantas na sanidade de híbridos de milho. Scientia Agraria Paranaensis, v.12, p.53-65, 2013.

LEONELLO, L.A.F.; CAZETTA, D.A.; FORNASIERI FILHO, D. Características agronômicas e qualidade comercial de cultivares de milho pipoca em alta população. Acta Scientiarum. Agronomy, v.31, p.215-220, 2009. DOI: 10.1590/S1807-86212009000200005.

MARCHÃO, R.L.; BRASIL, E.M.; XIMENES, P.A. Interceptação da radiação fotossinteticamente ativa e rendimento de grãos do milho adensado. Revista Brasileira de Milho e Sorgo, v.5, p.170-181, 2006.

MATTA, F. de P.; VIANA, J.M.S. Testes de capacidade de expansão em programas de melhoramento de milho pipoca. Scientia Agricola, v.58, p.845-851, 2001. DOI: 10.1590/ S0103-90162001000400029.

MORA, F.; SCAPIM, C.A. Predicción de valores genéticos del efecto de poblaciones de maíz evaluadas en Brasil y Paraguay. Agricultura Técnica, v.67, p.139-146, 2007. DOI: 10.4067/ S0365-28072007000200003.

MYERS, R.H.; MONTGOMERY, D.C.; ANDERSON-COOK, C.M. Response surface methodology: process and product optimization using designed experiments. $3^{\text {rd }}$ ed. New York: Wiley, 2009. 671p.

NUNES, H.V.; MIRANDA, G.V.; GALVÃO, J.C.C.; SOUZA, L.V. de; GUIMARÃES, L.J.M. Adaptabilidade e estabilidade de cultivares de milho-pipoca por meio de dois métodos de classificação. Revista Brasileira de Milho e Sorgo, v.1, p.78-88, 2002.

PACHECO, C.A.P.; CASTOLDI, F.L.; ALVARENGA, E.M. Efeito do dano mecânico na qualidade fisiológica e na capacidade de expansão de sementes de milho pipoca. Revista Brasileira de Sementes, v.18, p.267-270, 1996.

PEREIRA FILHO, I.A.; PACHECO, C.A.P.; CRUZ, J.C. (Ed.). A cultura do milho-pipoca. Brasília: Embrapa Informação tecnológica, 2010. 79p.

REVOREDO, M.D.; CAZETTA, J.O.; FORNASIERI FILHO, D. Características agronômicas e exportação de nutrientes em plantas de milho submetidas a diferentes densidades populacionais. Cultura Agronômica, v.18, p.103-111, 2009.

SANGOI, L.; ALMEIDA, M.L. de; GRACIETTI, M.A.; HORN, D.; SCHWEITZER, C.; SCHMITT, A.; BIANCHET, P. Rendimento de grãos, produção e distribuição de massa seca de híbridos de milho em função do aumento da densidade de plantas. Revista Brasileira de Agrociência, v.11, p.25-31, 2005.

SANGOI, L.; LECH, V.A.; RAMPAZZO, C.; GRACIETTI, L.C. Acúmulo de matéria seca em híbridos de milho sob diferentes relações entre fonte e dreno. Pesquisa Agropecuária Brasileira, v.37, p.259-267, 2002. DOI: 10.1590/ S0100-204X2002000300005.

SANGOI, L.; ZANIN, C.G.; SILVA, P.R.F. da; SALDANHA, A.; VIEIRA, J.; PLETSCH, A.J. Uniformidade no desenvolvimento e resposta de cultivares de milho ao incremento na população de plantas. Revista Brasileira de Milho e Sorgo, v.8, p.69-81, 2009.

SCAPIM, C.A.; PINTO, R.J.B.; AMARAL JÚNIOR, A.T.; MORA, F.; DANDOLINI, T.S. Combining ability of white grain popcorn populations. Crop Breeding and Applied Biotechnology, v.6, p.136-143, 2006. DOI: 10.12702/1984-7033.v06n02a04.

SILVA, P.R.F. da; SANGOI, L.; ARGENTA, G.; STRIEDER, M.L. Arranjo de plantas e sua importância na definição da produtividade em milho. Porto Alegre: Evangraf, 2006. 63p.

SISLEGIS: sistema de consulta à legislação. Versão 1.0. Brasília: Ministério da Agricultura, Pecuária e Abastecimento, 2011. Disponível em: <http://sistemasweb.agricultura.gov.br/sislegis/ action/detalhaAto.do? method=consultarLegislacaoFederal $>$. Acesso em: 13 dez. 2013.

STRIEDER, M.L.; SILVA, P.R.F. da; RAMBO, L.; BERGAMASCHI, H.; DALMAGO, G.A.; ENDRIGO, P.C.; JANDREY, D.B. Características de dossel e rendimento de milho em diferentes espaçamentos e sistemas de manejo. Pesquisa Agropecuária Brasileira, v.43, p.309-317, 2008. DOI: 10.1590/ S0100-204X2008000300004.

Received on October 17, 2011 and accepted on November 29, 2013 